\title{
Labouk orators
}

from Bevan

to Miliband

\section{EDITED BY}

ANDREW S. CRINES AND RICHARD HAYTON

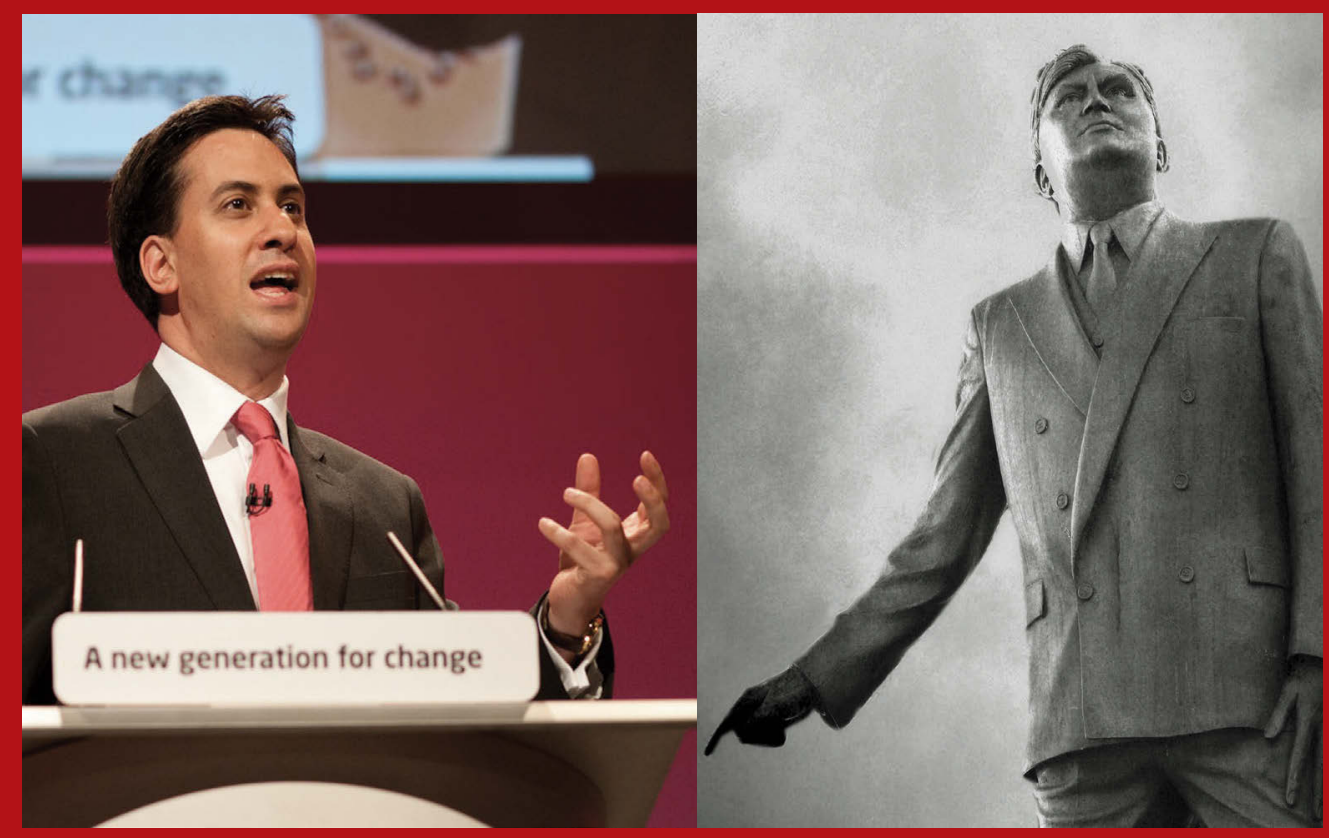


Andrew S. Crines and Richard Hayton - 9780719097959 Downloaded from manchesterhive.com at 04/26/2023 03:35:29PM 


\section{Labour orators from Bevan to Miliband}

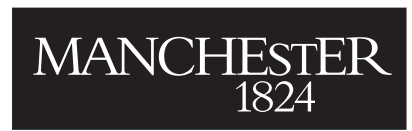

Manchester University Press 
Andrew S. Crines and Richard Hayton - 9780719097959 Downloaded from manchesterhive.com at 04/26/2023 03:35:29PM 


\title{
Labour orators from Bevan to Miliband
}

\author{
Edited by \\ Andrew S. Crines and Richard Hayton
}

Manchester University Press

Manchester and New York 
While copyright in the volume as a whole is vested in Manchester University Press, copyright in individual chapters belongs to their respective authors, and no chapter may be reproduced wholly or in part without the express permission in writing of both author and publisher.

Published by Manchester University Press

Oxford Road, Manchester M13 9NR, UK

and Room 400, 175 Fifth Avenue, New York, NY 10010, USA

www.manchesteruniversitypress.co.uk

Distributed in the United States exclusively by

Palgrave Macmillan, 175 Fifth Avenue, New York, NY 10010, USA

Distributed in Canada exclusively by

UBC Press, University of British Columbia, 2029 West Mall,

Vancouver, BC, Canada V6T 1 Z2

British Library Cataloguing-in-Publication Data

A catalogue record for this book is available from the British Library

Library of Congress Cataloging-in-Publication Data applied for

ISBN 9780719089800 hardback

First published 2014

The publisher has no responsibility for the persistence or accuracy of URLs for any external or third-party internet websites referred to in this book, and does not guarantee that any content on such websites is, or will remain, accurate or appropriate.

Typeset by Out of House Publishing 